\title{
Structure and properties of starch and flour of four Brazilian sweet potatoes (Ipomoea batatas) cultivars
}

\author{
Alana Gabrieli de Souza ${ }^{1}$, Daniel José Silva Viana ${ }^{2}$, \\ Alexandre Soares dos Santos ${ }^{3}$, Valter Carvalho de Andrade Júnior ${ }^{4}$, \\ Derval dos Santos Rosa ${ }^{1}$
}

\author{
${ }^{1}$ Engineering, Modeling and Applied Social Sciences Center (CECS), Federal University of ABC (Dos Estados Avenue, \\ 5001), Santo André, SP, Brasil. \\ ${ }^{2}$ Department of Biological Sciences, Federal University of the Jequitinhonha and Mucuri Valleys (JK Campi, Highway \\ MGT 367, Km 583, 5000), Diamantina, MG, Brasil. \\ ${ }^{3}$ Department of Basic Sciences, Federal University of the Jequitinhonha and Mucuri Valleys (JK Campi, Highway MGT \\ 367, Km 583, 5000), Diamantina, MG, Brasil. \\ ${ }^{4}$ Department of Agriculture, Federal University of Lavras (UFLA) (Aquenta Sol Street, s/n), Lavras, MG Brasil. \\ e-mail: alana_gs@live.com, daniel.silva@ufvjm.edu.br, alexandreletam@gmail.com, valterjr15@gmail.com, dervalrosa@ \\ yahoo.com.br.
}

\begin{abstract}
Starch is the most natural polymer used in the food and non-food industry. Sweet potato is among the world's most important, versatile and underexploited food crops; its composition depends on the planting strategy, climatic conditions, cultivar, geographic region, soil quality, and other. The physical-chemical characteristic and functional properties depends also of the amylose, amylopectin ratio and the molecular components of amylose and amylopectin. In this study, the structural and physicochemical properties of starches from four sweet potato genotypes cultivated in Brazil were compared. Starch granules of roots of sweet potato all exhibited oval and irregular shapes with granule sizes ranging from 8 to 30 $\mu \mathrm{m}$. Amylose contents of roots of sweet potato starches differed from 9.7 to $15.1 \%$. Ratios of 1045/1022 and 1022/995 $\mathrm{cm}^{-1}$ of Fourier transform infrared spectra varied in the range of 0.8114-0.8558 and 0.9046-0.9347, respectively, which means that the genotypes present different structure ordering. Also, the digestibility, swelling power, and solubility showed some differences between the starches, probably due to the differences in amylose and amylopectin contents and granules sizes. The different genotypes showed similar thermal stability. Our study indicated the sweet potato genotypes are greatly influenced the amylose content, structure order, the degree of short-range order, granule size, digestibility, swelling power and solubility of sweet potato genotypes.
\end{abstract}

Keywords: Biopolymer; Carbohydrate; Ipomoea batatas; new starch quality.

\section{INTRODUCTION}

One of the most useful polymers in the food and non-food industry is starch. Starch is a biological macromolecule, mainly isolated from corn, potato, rice or wheat, but researches have broadened their knowledge about starch through the examination of polymers isolated from other plants, such as the sweet potato. Sweet potatoes are grown in 111 countries, with a worldwide production of 105.19 million tons, covering an area of approximately 8.62 million hectares planted, with approximately $85.4 \%$ of production in Asia, only $11,6 \%$ in Africa and 3\% in the rest of the world. Only $2.4 \%$ of production is in the Americas [1-3]. It is a root with positive attributes such as high productivity, adaptability, short production cycle and a high nutritional content [4]. Sweet potato is among the world's most important, versatile and underexploited food crops [5]. It is the sixth most important world crop, after rice, wheat, potato, corn and cassava [4].

The sweet potato stands out for its ability to produce energy per unit area, rusticity, adaptability to different types of soil and climate, high tolerance to drought, short cycle and low cost of production [6]. It can also be processed into flour, which is less bulky and more stable than the highly perishable fresh root [7]. While sweet potato is generally consumed cooked, the dried form of the root is also used in the production of flour, which is used in the manufacture of bread and cereal products [4]. Also, according to the US Department of Agriculture (USDA), studies suggest that sweet potatoes may 
have two to three times as many fermentable carbohydrates for fuel production as corn.

The chemical composition of sweet potato can vary widely depending on the planting strategy, climatic conditions, cultivar, geographic region, soil quality, and other. In the case of the starch, its use in the industry depends in addition to its physical-chemical characteristic and functional properties also of the amylose, amylopectin ratio and the molecular components of amylose and amylopectin. Native starch occurs in the form of semi-crystalline granules, mainly composed of two glucans. Amylose content, chain length distribution of amylopectin, and the way they are organized within the granules are the major determinants for the structural and functional properties of starch granules. The complex structure of starch granules is the major determinant of starch functionality for the different applications. Hence, a comprehensive characterization of starch structures is essential for a better understanding of starch functionality [8].

In the case of sweet potato, the physico-chemical characterization of the different genotypes can contribute significantly to the wide use of the crop, especially in industry, with different objectives such as ethanol production $[6,9]$ the transcriptomic variation associated with starch properties in SR has not been quantified. In this study, we measured the starch and sugar contents and analyzed the transcriptome profiles of SRs harvested from sweet potatoes with high, medium, and extremely low starch contents, at five developmental stages [65, 80, 95, 110, and 125 days after transplanting (DAP or the development of new products from sweet potato roots. However, there are few studies on the physical and chemical properties of by-products generated from sweet potato, such as flour and starch [10].

This study was conducted to investigate the functional properties of roots of different genotypes of sweet potato. This is important to understand the effect of interactions among the composition and other variables on the quality attributes of sweet potato flour and starch.

\section{MATERIALS AND METHODS}

All the cultivars of sweet potato tubers used in this study (four genotypes: G1; G2; G3; and G4) were obtained in Alto Vale do Jequitinhonha, MG, Brazil. The genotypes were chosen empirically from a few cultivars. The studied genotypes were collected in different regions of Brazil and are part of the germplasm bank of UFVJM, MG. Genetic diversity studies using morphological and molecular descriptors showed the great genetic variability between genotypes [11]. The clones were evaluated at 180 days after planting, where $400 \mathrm{~g}$ of roots of each clone were ground and oven dried with forced air ventilation at $65^{\circ} \mathrm{C}$. Samples were labeled and packed in plastic pots for further quality analyzes of the clones. Figure 1 (a) shows the different steps of cultivation of sweet potato and its starches.
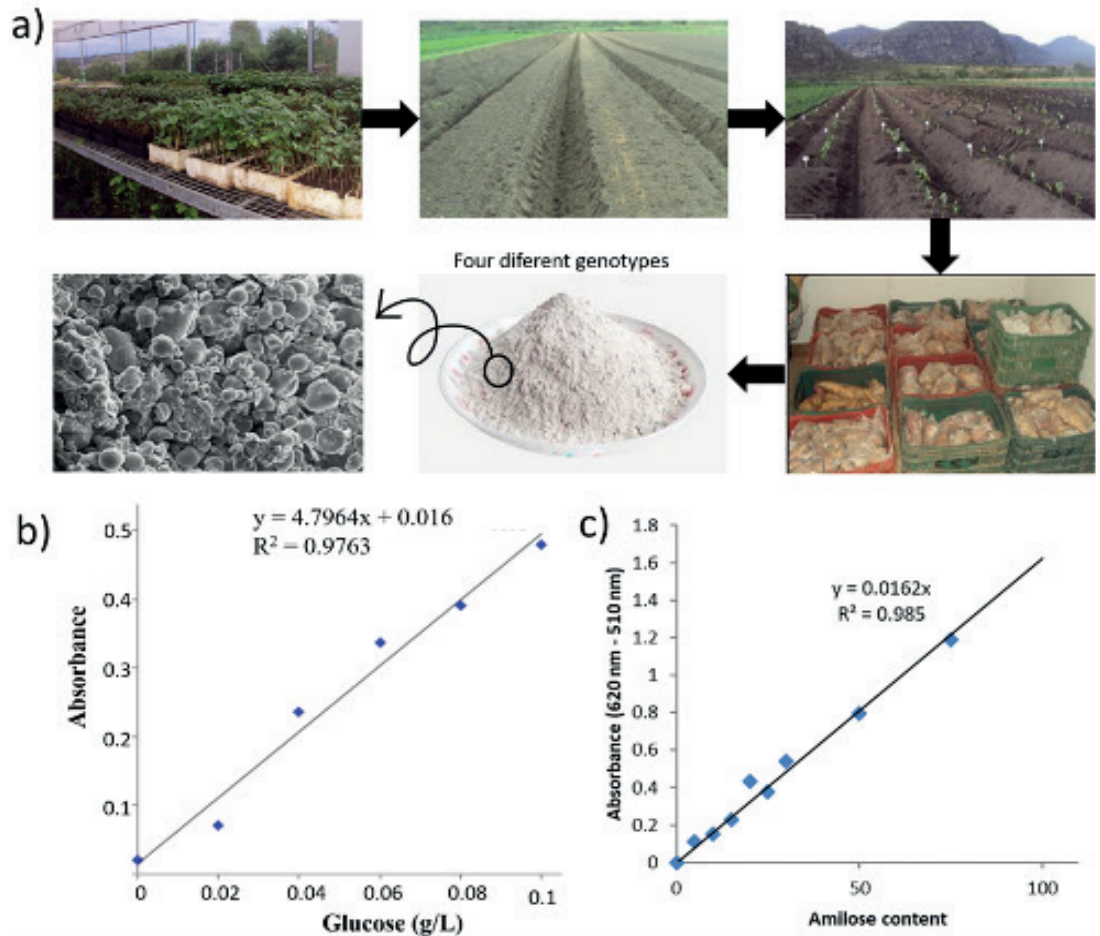

Figure 1: (a) Soil preparation, sweet potato (Ipomoea batatas) cultivation, harvest and starch obtained at Fazenda Forquilha, MG, Brazil; (b) the regression equation for starch content and (c) the regression content for amylose content. 


\subsection{Characterization}

\subsubsection{Determination of starch content}

Samples of sweet potato root flour $(0.2 \mathrm{~g})$ were individually added in $500 \mu \mathrm{L}$ solution containing $10 \mu \mathrm{L}$ alpha-amylase (Liquozyme ${ }^{\circledR}$ Novozymes), and the solution was incubated at $90{ }^{\circ} \mathrm{C}$ for $30 \mathrm{~min}$ to hydrolyze the digestible starch. After that, the $10 \mu \mathrm{L}$ amyloglucosidase enzyme preparation (Sprizyme ${ }^{\circledR}$ Novozymes) was added and taken to the water bath at $60{ }^{\circ} \mathrm{C}$ for $1 \mathrm{~h}$. The released glucose was quantified by the enzymatic-colorimetric GOD-POD method. The starch content was calculated based on the conversion of the glucose to its equivalent in starch, multiplying the first value by 0.9 . Fig. 1 (b) shows the analytical curve of glucose used for the determination of starch.

\subsubsection{Determination of amylose and amylopectin contents}

Amylose and amylopectin contents were determined by the 96-weel plane iodine method (Wolf et al. 1970) [12]. First, $5 \mathrm{mg}$ of sweet potato flour samples were weighed to centrifuge microtubes. Next, $1 \mathrm{~mL}$ of $90 \%$ DMSO in water was added and the mixture was heated to $95{ }^{\circ} \mathrm{C}$ for $60 \mathrm{~min}$, stirring every $10 \mathrm{~min}$. The extractive solutions were cooled for $5 \mathrm{~min}$, and 100 $\mu \mathrm{L}$ from each solubilized starch samples were transferred to 96-well plates. After the samples were placed into the 96-well plates, $100 \mu \mathrm{L}$ of $90 \%$ DMSO with $3.04 \mathrm{~g} / \mathrm{L}$ iodine was added to each well and plate was shaken for 2 min. A subsample $(20 \mu \mathrm{L})$ from each well was removed and added to an empty plate. Then, $180 \mu \mathrm{L}$ of deionized water was added to each well and plate was shaken for $2 \mathrm{~min}$. After agitation, the samples were analyzed for absorbance at $620 \mathrm{~nm}$ and $510 \mathrm{~nm}$. The absorbance was blanked with the control for final abs620 and abs510 reading. The regression equation was determined for the standard curves in each well using the difference between the absorbance values at $620 \mathrm{~nm}$ and $510 \mathrm{~nm}$. The amylose content was determined using the following equation: (based on Fig. 1 (c)):

$$
\text { amylose content }=\frac{a b s \text { s } 620-\text { abs } 510}{\text { slope of the regression }}
$$

The amylopectin content was determined through the difference between the starch concentration and the amylose concentration. The analysis was conducted in triplicate.

\subsubsection{Fourier transform infrared spectroscopy}

FTIR was conducted using a Frontier94942 (PerkinElmer, USA) in the range from 400 to $4000 \mathrm{~cm}^{-1}$, with 64 scans and a resolution of $4 \mathrm{~cm}^{-1}$. It was used an attenuated total reflectance accessory, and the analysis was conducted with in the samples in powder form.

\subsubsection{Scanning electron microscopy}

The morphology and sizes of the starch granules were analyzed by scanning electron microscopy (SEM). The samples, in powder form, was added into an aluminum stub, which was sputter-coated with gold $(20 \mathrm{~nm})$, was examined in a JEOL JCM 6010, operating with an accelerating voltage of $5 \mathrm{KV}$.

\subsubsection{Digestibility of starch}

The digestibility of sweet potato starches was analyzed using commercial amylolytic enzymes. The digestibility was performed from $0.5 \mathrm{~g}$ of the dehydrated sweet potato root samples added in $3.5 \mathrm{~mL}$ of acetate buffer $(100 \mathrm{mM}$; $\mathrm{pH}=4)$ containing $10 \mu \mathrm{L}$ of alpha-amylase (AGXXL Novozymes) and $10 \mu \mathrm{L}$ of amyloglucosidase (Spirizyme Novozymes). After homogenization, the samples were incubated in a water bath at $60{ }^{\circ} \mathrm{C}$ for 15 minutes. Next, for the denaturation of the enzymes, the reaction was incubated in a water bath at $95{ }^{\circ} \mathrm{C}$ for five minutes. After cooling, the sample was swollen with distilled water to $100 \mathrm{~mL}$. Glucose concentrations were determined by the GOD-POD method. The analysis was conducted in triplicate. The digestibility (DS) was calculated using the following equation, where GC is the glucose content and SC the starch content:

$$
D S(\%)=\frac{(G C / 1.1)}{S C} * 100
$$




\subsubsection{Swelling power and solubility}

The swelling capacity and solubility of the starch contained in the flours of sweet potato genotypes were performed at different temperatures $\left(50{ }^{\circ} \mathrm{C}, 70{ }^{\circ} \mathrm{C}\right.$ and $\left.90^{\circ} \mathrm{C}\right)$ and determined according to the method described by Paraginski et al. (2018) with modifications (Paraginski et al. 2019) [13]. The samples (0.35 g) were mixed with $12.5 \mathrm{~mL}$ of distilled water. The suspensions were heated at $50{ }^{\circ} \mathrm{C}, 70{ }^{\circ} \mathrm{C}$ and $90{ }^{\circ} \mathrm{C}$ for $30 \mathrm{~min}$. The gelatinized samples were then cooled to room temperature and centrifuged at $4000 \mathrm{rpm}$ for $15 \mathrm{~min}$. The supernatant was dried at $100{ }^{\circ} \mathrm{C}$ to a constant weight to quantify the soluble fraction. The swelling power was expressed as the weight ratio of wet sediment to the weight of the initial dry sample (deducting the amount of soluble starch). The analysis was conducted in triplicate.

\subsubsection{Thermogravimetric analysis}

TGA was carried out using STA 6000 instrument (Perkin Elmer, USA). The samples were heated from 50 to $500{ }^{\circ} \mathrm{C}$ with a heating rate of $20^{\circ} \mathrm{C} / \mathrm{min}$ under a nitrogen flow. The initial decomposition temperatures, measured at $10 \%$ weight loss, were used to compare the thermal stabilities.

\subsubsection{Statistical analysis}

The results are expressed as the mean values, and the standard deviation is reported. Data were analyzed by analysis of variance (ANOVA), and when significant differences $(p<0.05$ ) were found, they were compared using a multiple range test. Data were analyzed with the statistical program Sisvar.

\section{RESULTS AND DISCUSSIONS}

\subsection{Starch, amylose and amylopectin contents}

Starches are the most valuable components in sweet potato. The starch may have been affected by genetics, culture development, and synthesis processes, also causing changes in the contents of proteins, lips, and minerals such as phosphorous [7]. During bioethanol production, the starch content is an important characteristic that affects the fermentation efficiency [14]. Table 1 presents the starch contents of the different genotypes, and it was observed a wide variation in the contents, with G1 containing the highest starch content (59.1\%) and G4 containing the lowest (51.6\%). The average value of starch content was $55.7 \%$.

Table 1: Starch, amylose and amylopectin contents in the different sweet potato studied.

\begin{tabular}{c|c|c|c}
\hline Genotypes & Starch (\%) & Amylose (\%) & Amylopectin (\%) \\
\hline G1 & $59.1 \pm 1.5^{\mathrm{a}}$ & $11.6 \pm 1.8^{\mathrm{b}}$ & $88.4 \pm 1.7^{\mathrm{b}}$ \\
\hline $\mathrm{G} 2$ & $56.6 \pm 0.3^{\mathrm{a}}$ & $15.1 \pm 2.0^{\mathrm{a}}$ & $84.9^{\mathrm{a}} \pm 2.0^{\mathrm{c}}$ \\
\hline $\mathrm{G} 3$ & $55.7 \pm 2.6^{\mathrm{a}}$ & $9.7 \pm 2.9^{\mathrm{c}}$ & $90.3 \pm 2.9^{\mathrm{a}}$ \\
\hline G4 & $51.6 \pm 1.9^{\mathrm{b}}$ & $12.2 \pm 1.9^{\mathrm{b}}$ & $87.8 \pm 1.9^{\mathrm{b}}$ \\
\hline Coefficient of variation (\%) & 3.6 & 8.2 & 1.1 \\
\hline
\end{tabular}

*Values in a column with the same superscripts do not differ by the "Scott-Knott" test at $5 \%$ probability

Therefore, when screening genotypes for bioethanol fermentation, the stability of these properties in unprocessed sweet potato roots over time should be considered. Fresh sweet potato roots contain lots of water and a variety of enzymes and microorganisms. The content of starch and transformation processes of various enzymes is highly correlated [14]. Differences in the chemical compositions of starch could affect its digestibility, susceptibility to retrogradation, and physicochemical properties as previously reported by Boukid et al. (2018) [15]. The observed values are in agreement with the literature [16].

The sweet potato starch consists of amylose and amylopectin, the length of glucan chains and the proportion of amylose and amylopectin molecules govern the size, structure, and function of starch [17]. The amylose content of the different genotypes analyzed can be found in Table 1. Amylose content of the different samples ranged between $9 \%$ and $15 \%$ and was lower than the range of values (10-21\%) reported by Olatunde et al. (2015) [5]. The genotype G2 present the hi- 
ghest value, differing statistically from the other genotypes. Depending on the botanical source of the starch and the climatic and soil conditions during grain development, the amylose content of starch has been reported to vary widely [18, 19].

\subsection{Fourier transform infrared spectroscopy}

The FTIR technique was used to explore the structural organization of the starches. The FTIR spectra of all the samples are shown in Figure 2. The band at $3290 \mathrm{~cm}^{-1}$ is assigned to the stretching vibration of the O-H group, and the bands at 2900 $\mathrm{cm}^{-1}$ were ascribed to $\mathrm{C}-\mathrm{H}$ bond stretching associated with the ring methane hydrogen atoms. The bands in the region of $1365-1413 \mathrm{~cm}^{-1}$ are assigned to the $\mathrm{C}-\mathrm{H}$ bending vibrations, and the peak at $1640 \mathrm{~cm}^{-1}$ is usually attributed to the bound water present in the polysaccharide.

All the peaks in the fingerprint region of starches (between 1500 and $400 \mathrm{~cm}^{-1}$ ) were observed for all the studied genotypes [20]. Most of the glycosidic $\alpha-1 \rightarrow 4$ linkages of the starch were found within the bands of $1150-1023 \mathrm{~cm}^{-1}[16$, 21]. It was observed that the band $1000 \mathrm{~cm}^{-1}$ show a difference of intensity, according to the analyzed genotype. This was ascribed to C-O-H and has been correlated to the amorphous state in starch [20, 22]. The band intensity ratio of 1045/1022 $\mathrm{cm}^{-1}$ is frequently used to measure the degree of short-range order in starch, and that of 1022/995 $\mathrm{cm}^{-1}$ can be used to quantify the proportion of amorphous to ordered structure of starch [23]. The values obtained to the studied samples are present in Figure 2. This result has significant importance, because the more amorphous the material is the higher its affinity with water. Also, these values indicated the short-range ordered structure of sweet potato starch does not depend significantly on the genotype of sweet potato [23].

Further, peaks at 570 and $530 \mathrm{~cm}^{-1}$ were attributed to skeletal vibrations of pyranose ring [20]. There was no distinct difference in the vibration bands of $\mathrm{O}-\mathrm{H}, \mathrm{C}-\mathrm{H}$ and $\mathrm{C}-\mathrm{O}$ groups of starch among different sweet potato cultivars which might be because the basic chemical structure of polysaccharides is similar, which reflected in their similar peaks [20, 21].

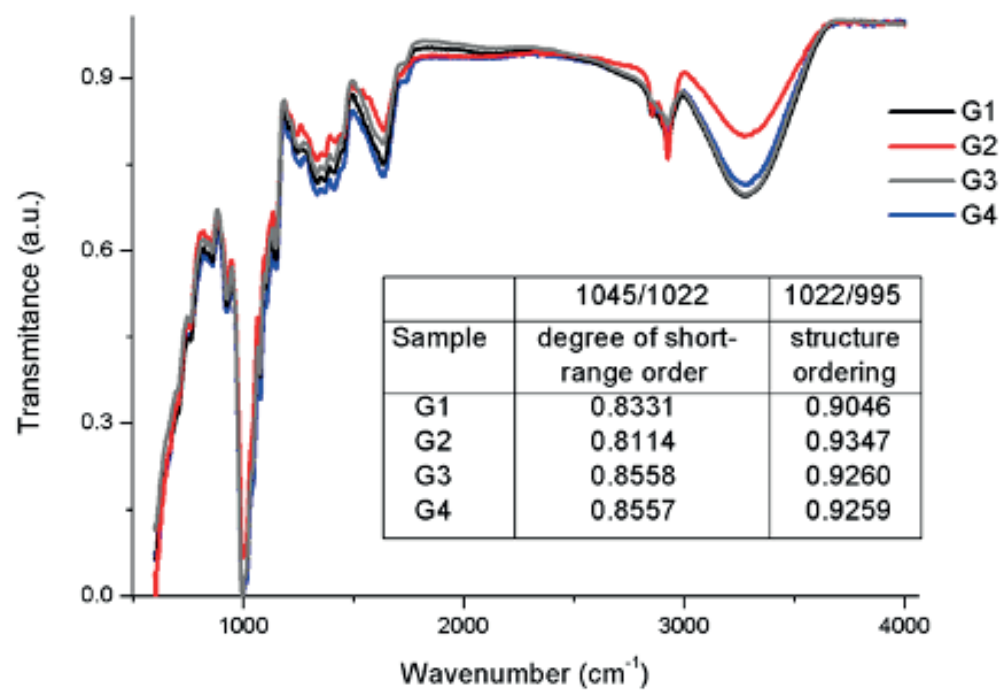

Figure 2: FT-IR spectra of four genotypes of sweet potato starches. The abbreviations of sweet potato genotypes are explained in section 2.1 .

\subsection{Scanning electron microscopy}

There have been several studies reporting the importance of granule size on the pasting, rheological, digestive, baking and chemical reactivity properties of starches $[13,16,20,23,24]$. The morphology of the starch granules was observed using SEM (Figure 3). It was found that the samples showed granular morphologies, and the granules displayed oval and irregular shapes, which were similar to those of starch granules from other pulse crops as described by Li et al. (2019) [25]. 

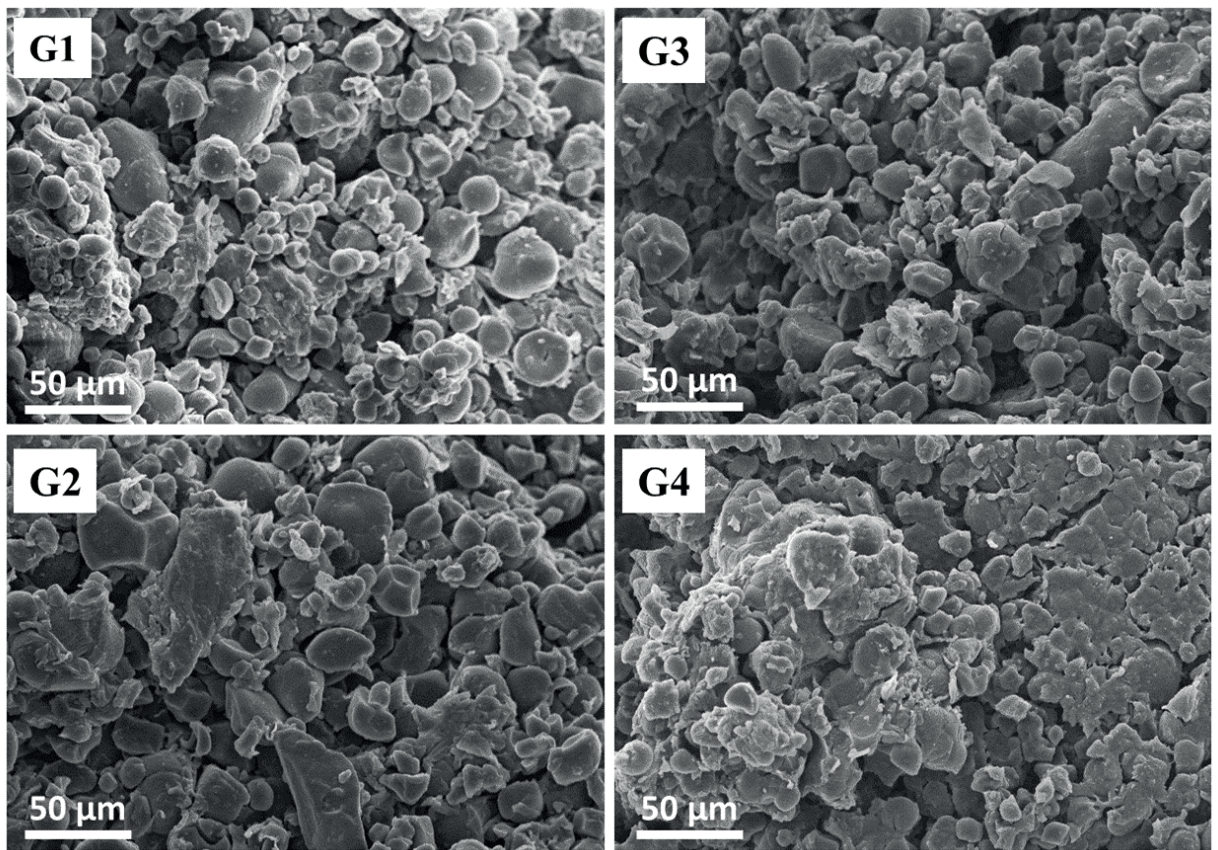

Figure 3: Scanning electron micrographs of the isolated sweet potato starches.

The surface of granules was mostly smooth, with some grooves, indentations, pore, scraps, cracks or fissures [15]. During the milling, starch granules are subjected to various forces such as compression, impact, shear, and attrition, which are likely to cause physical breakdown or granules, producing a range of fragmented or broken granules [25, 26]. Also, some starch granules formed agglomerates. Similar results were reported in the literature [7, 23].

The sweet potato particle size distribution is present in Figure 4. Granules number distribution was based on the proportions of equivalent spheres diameters. In general, the granules of all the genotypes was around $18 \mu \mathrm{m}$. All the samples showed a high heterogeneity of particles sizes. If compared to starches from different genotypes, the distribution of the size of the G3 is similar to that observed for G4. Only the G1 clone had a higher diameter of the starch granules, standing out in relation to the other clones studied here. According to Boukid et al. (2018), there is a considerable genetic effect on starch granule distribution [15]. These differences in chemical, structural properties and granule sizes of all the genotypes starch granules could be due to diversity in genes encoding starch biosynthetic enzymes and environmental factors acting on the genes and enzyme activities during plant growth [23].
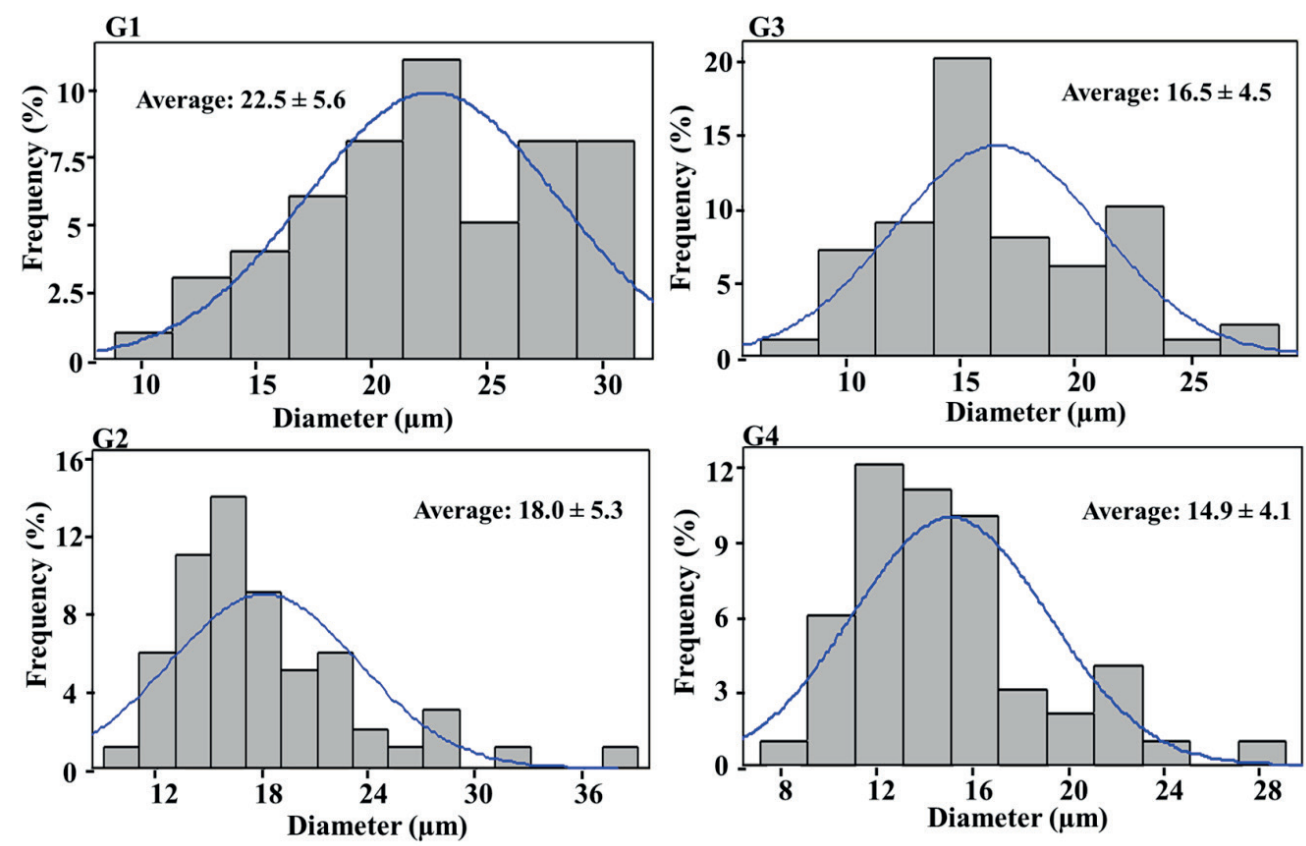

Figure 4: Size distribution histogram for all genotypes studied. 


\subsection{Digestibility of starch}

The digestibility of the sweet potato genotypes is: $\mathrm{G} 1=83.5 \pm 6.9$; $\mathrm{G} 2=64.9 \pm 3.8 ; \mathrm{G} 3=68.3 \pm 2.6$; and G4 $=73.7 \pm 3.2$. These values indicate that the genotypes are highly susceptible to the enzymatic saccharification. Also, the starches from different sweet potato varieties had different granule sizes, amylose contents, relative crystallinities, and ordered degrees, which might lead to different digestion properties $[16,21]$. The digestibility of the starch is a solid solution two-phase reaction in which the enzyme needs first to diffuse to and adsorb on the solid substrate before catalyzing the cleavage of glycosidic linkages. Diffusion of enzymes onto the starch and then inside the granules may be rate-limiting steps in enzymatic hydrolysis [27].

The digestibility is affected by the amylose contents, and according to Li et al. (2018), the higher levels of amylose contributes to a less porous granular structure, which results in lower digestibility [17, 28]. In this work, the genotype G2 showed the higher amylose content and ordered arrangement, and the lower digestibility, which is coherent with the expected. Also, previous research has demonstrated that the internal structure of starch granules is another critical factor that can significantly influence the digestibility of the starch. So, besides the genotype G1 present a more amorphous (less ordered) structure, a fact that contributes to the digestibility of the starch, it is possible that this genotype had internal voids and internal fissures that cannot be observed by SEM analysis [28]. These results demonstrated that different genotypes might have different properties, which has influences in your possibilities of application.

\subsection{Swelling power and solubility}

Both swelling power and solubility properties of the sweet potato genotypes are shown in Table 2 . These properties represent evidence of interaction between the amorphous and crystalline areas. Furthermore, it is influenced by amylose and amylopectin contents. Comparing the same temperatures, it is possible to observe that the genotypes do not show significant differences in the swelling power. This characteristic shows a tendency that can be correlated with the amylopectin contents [16]. The low swelling power of sweet potato starch, when compared with other carbohydrates in the literature, has been attributed to a higher degree of intermolecular association and higher amylose content compared to other flours [13, 25].

Table 2: Swelling power and solubility properties of the sweet potato genotypes studied.

\begin{tabular}{|c|c|c|c|}
\hline \multirow{2}{*}{ GENOTYPES } & \multicolumn{3}{|c|}{ SWELLING POWER (G/G) } \\
\hline & $50^{\circ} \mathrm{C}$ & $70^{\circ} \mathrm{C}$ & $90^{\circ} \mathrm{C}$ \\
\hline G1 & $2.94 \pm 0.03{ }^{\mathrm{a}} \mathrm{C}$ & $5.80 \pm 0.42{ }^{a b}$ & $7.21 \pm 0.40_{\mathrm{A}}^{\mathrm{a}}$ \\
\hline $\mathrm{G} 2$ & $2.79 \pm 0.08^{a}{ }_{B}^{a}$ & $6.28 \pm 0.26^{\mathrm{a}}{ }_{\mathrm{A}}$ & $6.57 \pm 0.18^{\mathrm{b}}{ }_{\mathrm{A}}$ \\
\hline G3 & $2.90 \pm 0.08^{a}{ }_{C}^{a}$ & $5.95 \pm 0.21_{\mathrm{B}}^{\mathrm{ab}}$ & $6.73 \pm 0.06^{\mathrm{ab}}{ }_{\mathrm{A}}$ \\
\hline G4 & $3.19 \pm 0.36^{\mathrm{a}}{ }_{\mathrm{B}}$ & $5.46 \pm 0.07_{\mathrm{A}}^{\mathrm{b}}$ & $5.55 \pm 0.18_{\mathrm{A}}^{\mathrm{c}}$ \\
\hline Average & $2.95_{\mathrm{C}}$ & $5.87_{\mathrm{B}}$ & $6.51_{\mathrm{A}}$ \\
\hline Coefficient of variation (\%) & & 4.76 & \\
\hline \multirow{2}{*}{ GENOTYPES } & \multicolumn{3}{|c|}{ SOLUBILITY (\%) } \\
\hline & $50^{\circ} \mathrm{C}$ & $70^{\circ} \mathrm{C}$ & $90^{\circ} \mathrm{C}$ \\
\hline G1 & $16.17 \pm 1.34{ }_{\mathrm{A}}^{\mathrm{c}}$ & $12.71 \pm 0.49^{\mathrm{b}}{ }_{\mathrm{B}}$ & $12.57 \pm 0.73^{\mathrm{b}}{ }_{\mathrm{B}}$ \\
\hline $\mathrm{G} 2$ & $22.42 \pm 1.06^{\mathrm{b}}{ }_{\mathrm{A}}$ & $7.16 \pm 0.88^{c}{ }_{C}^{c}$ & $12.70 \pm 0.78^{b}$ \\
\hline G3 & $16.90 \pm 1.32{ }_{\mathrm{A}}^{\mathrm{c}}$ & $8.06 \pm 0.54{ }_{C}^{\mathrm{c}}$ & $12.59 \pm 1.59^{\mathrm{b}}$ \\
\hline G4 & $27.76 \pm 2.64{ }_{\mathrm{A}}^{\mathrm{a}}$ & $17.17 \pm 1.67{ }_{\mathrm{C}}^{\mathrm{a}}$ & $20.67 \pm 3.10_{B}^{a}$ \\
\hline Average & $20.81_{\mathrm{A}}$ & $11.27_{\mathrm{C}}$ & $14.63_{\mathrm{B}}$ \\
\hline Coefficient of variation $(\%)$ & \multicolumn{3}{|c|}{10.06} \\
\hline
\end{tabular}

*Averages followed by the same superscripts in the columns and subscript in the lines do not differ from each other by the Tukey test at the $5 \%$ level of significance. 
Considering the solubility results at $50{ }^{\circ} \mathrm{C}$, which, according Castanha et al. (2018) is slightly higher than the onset temperature of the samples, it was possible to observe the higher values of solubility, which can be explained by the amylose fractions that may have leached from the granules at this temperature [29]. At $70{ }^{\circ} \mathrm{C}$, all water available for gelatinization was entirely absorbed by the granules, and there was no soluble part to evaluate. Regarding starch solubility, at $90{ }^{\circ} \mathrm{C}$, the explanation for $70{ }^{\circ} \mathrm{C}$ can be applied, and the genotypes G1, G2 and G3 showed the same results, and G4 showed the highest value, $20.7 \%$. These values are in accordance with the literature. Also, the decrease in the water absorption capacity is expected, when compared $90{ }^{\circ} \mathrm{C}$ and $50{ }^{\circ} \mathrm{C}$ due to the thermal properties of the starch.

The obtained data could not allow a specific indication of the reasons behind swelling and solubility variations. It was reported that the difference in the degree of availability of water binding sites might contribute to the change in water retention capacity among different starches $[15,30]$. The solubility is affected by granule size, amylose content, fine amylopectin structure, crystalline structure, and protein and lipid contents [16]. Also, factors that may influence the solubility of starches are the source, swelling power, inter-associative forces within the amorphous and crystalline domains, and presence of other components (phosphorous, etc.) [15]. This parameter is important for the potential application of starch-based products that may require water insolubility, such as biodegradable packaging materials. On the other hand, the solubility in water might be useful for applications of coatings or food encapsulation. So, the studied genotypes can be applied to different products, depending on their intrinsic properties [30].

\subsection{Thermogravimetric analysis}

TGA has been widely used to study the thermal stability and decomposition of starch. As shown in Figure 5(a), TGA curves of four genotypes of sweet potato starches were very similar, indicating these starches has similar thermal stability [23]. Notably, all starches exhibited two weight loss stages, as can be observed in Figure 5(b). The first weight loss stage was in the range of $185-240{ }^{\circ} \mathrm{C}$. The second is in the range $247-350{ }^{\circ} \mathrm{C}$ and is attributed to the thermal decomposition of starches [23]. In this stage, depolymerization of starch macromolecule occurred in temperatures near to $300{ }^{\circ} \mathrm{C}$ [31].

DTG, the first derivative TGA, can further supply information on the relative decomposition rate of starch. The peak maxima in the DTG curve represents the maximum rate of weight loss, and the values can be observed in Figure 5(b). Considering the observed thermal properties, the studied starches present an excellent potential for different applications, such as microencapsulation, packaging, biodegradable materials, and others. The main properties needed for all these applications are low flavor and color contents, biodegradability, emulsifying capacity, homogeneity in shape and size and relatively low-cost, which makes the sweet potato starch a promising material.
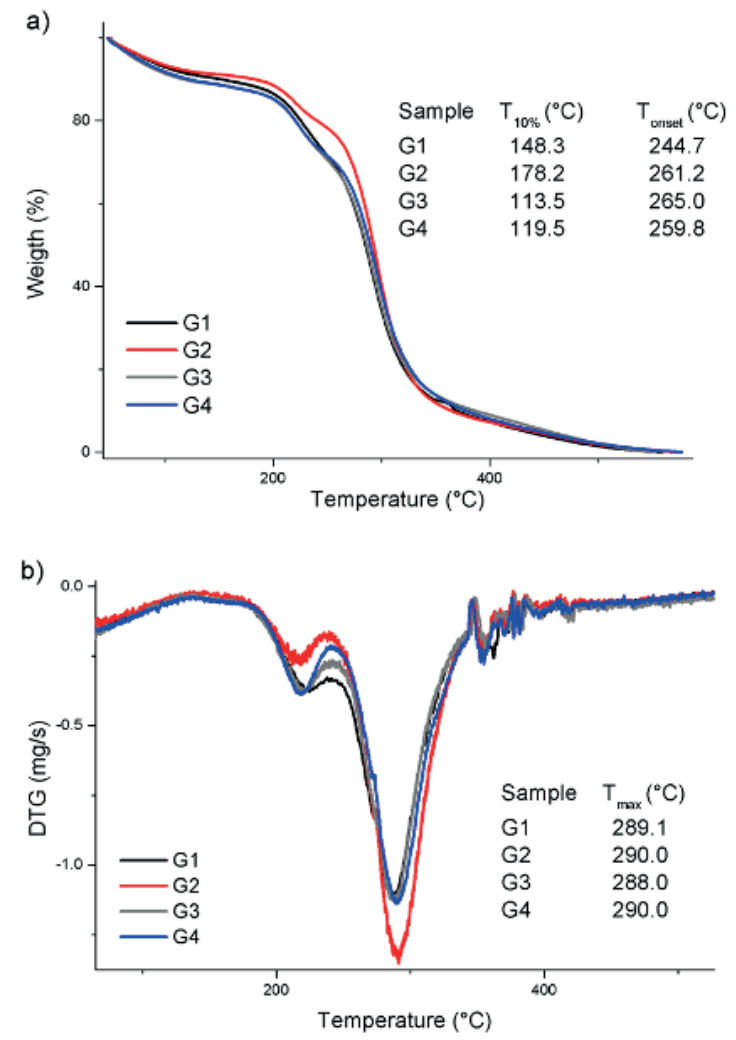

Figure 5: Thermograms (a) TG of thermal decomposition and (b) its derivative of all the genotypes of sweet potato starch 


\section{CONCLUSION}

There is an influence of the sweet potato genotype on the amylose and amylopectin content, structure order, the degree of short-range order, granule size, digestibility, swelling power and solubility of sweet potato. However, all the polysaccharides exhibited the same characteristic peaks on the Fourier transform infrared spectroscopy analysis and thermal stability. Our study could provide novel information on the relationship between the cultivar of sweet potato genotypes and the properties of its starches.

\section{ACKNOWLEDGMENTS}

The authors are grateful to UFABC, CNPq and the Central Experimental Multiusuário (CEM/UFABC) for technical assistance, and the company Multiverde Papéis Especiais Ltda. by the material supplied.

\section{BIBLIOGRAPHY}

[1] JOHNSON, T., WILSON, N., WOROSZ, M.R., et al., UNITED STATES DEPARTMENT OF AGRICULTURE ECONOMIC RESEARCH SERVICE, https://www.ers.usda.gov/webdocs/publications/39544/52774_vgs-355-sa1.pd$\mathrm{f} ? \mathrm{v}=42125$, accessed in 2019, September.

[2] SILVA, J.G., FOOD AND AGRICULTURE ORGANIZATION OF THE UNITED NATIONS - The state of food and agriculture, http://www.fao.org/3/a-i7658e.pdf, accessed in 2019, September.

[3] DEPARTMENT, FOOD AND AGRICULTURE ORGANIZATION OF THE UNITED NATIONS - Sweet potatoes production, http://www.fao.org/faostat/en/\#search/Sweet\%20potatoes, accessed in 2019, September.

[4] TRANCOSO-REYES, N., OCHOA-MARTÍNEZ, L.A., BELLO-PÉREZ, L.A., et al., "Effect of pre-treatment on physicochemical and structural properties, and the bioaccessibility of $\beta$-carotene in sweet potato flour", Food Chemistry, v. 200 , pp. 199-205, Jun. 2016.

[5] OLATUNDE, G.O., HENSHAW, F.O., IDOWU, M.A., et al., "Quality attributes of sweet potato flour as influenced by variety, pretreatment and drying method”, Food Science \& Nutrition, v. 4, n. 4, pp. 623-635, Jul. 2016.

[6] VIANA, D.J.S., PINTO, S.S.S., DIAS, K.P.F., et al., "Evaluation of productivity of sweet potato genotypes for first and second generation bioethanol production", African Journal of Biotechnology, v. 16, n. 49, pp. 2289-2298, Dec. 2017.

[7] MENDOZA, J., VARGAS, P., EVANGELISTA, M., et al., "Physicochemical characteristics of three accessions of sweet potato cultivated by traditional growers of Vale do Ribeira, Sao Paulo State, Brazil”, v. 1194, pp. 953-958, 2018.

[8] WANG, S., LI, P., YU, J., et al., "Multi-scale structures and functional properties of starches from Indica hybrid, Japonica and waxy rice", v. 102, pp. 136-143, sept. 2017.

[9] ZHANG, K., WU, Z., TANG, D., et al., "Comparative Transcriptome Analysis Reveals Critical Function of Sucrose Metabolism Related-Enzymes in Starch Accumulation in the Storage Root of Sweet Potato", Frontiers in Plant Science, v. 22, n. 8, pp. 914-929, Jun. 2017.

[10] KUSUMAYANTI, H., HANDAYANI, N.A., SANTOSA, H. "Swelling Power and Water Solubility of Cassava and Sweet Potatoes Flour”, Procedia Environmental Sciences, v. 23, pp. 164-167, 2015.

[11] DE ANDRATE, E.K.V., DE ANDRADE JUNIOR, V.C., LAILA, M.L., et al., "Genetic dissimilarity among sweet potato genotypes using morphological and molecular descriptors”, Acta Scientiarum, v. 39, n. 4, pp. 447-455, Oct-Dec. 2017.

[12] WOLF, M.J., MELVIN, E.H., GARCIA, W.J., et al., "Amylose Determination in Dimethyl Sulfoxide Extracts of Maize", Cereal Chemistry, v. 47, n. 4, pp. 437-446, 1970.

[13] PARAGINSKI, R.T., COLUSSI, R., DIAS, A.R.G., et al., "Physicochemical, pasting, crystallinity, and morphological properties of starches isolated from maize kernels exhibiting different types of defects", Food Chemistry, v. 274, pp. 330336, Feb. 2019.

[14] TIAN, S-Q.T., ZHAO, R-Y., ZHAO, J-L., "Production of Bioethanol from Sweet Potato Tubers with Different Storage Times", BioResources, v. 13, pp. 4795-4806, 2018.

[15] BOUKID, F., VITTADINI, E., PRANDI, B., et al., "Insights into a century of breeding of durum wheat in Tunisia: The properties of flours and starches isolated from landraces, old and modern genotypes", $L W T$, v. 97, pp. 743-751, Nov. 2018.

[16] GUO, K., LIU, T., XU, A., et al., "Structural and functional properties of starches from root tubers of white, yellow, and purple sweet potatoes", Food Hydrocolloids, v. 89, pp. 829-836, Apr. 2019. 
[17] TAN, X., GU, B., LI, X., et al., "Effect of growth period on the multi-scale structure and physicochemical properties of cassava starch", International Journal of Biological Macromolecules, v. 101, pp. 9-15, Aug. 2017.

[18] PACHUAU, L., DUTTA, R.S., ROY, P.K., et al., "Physicochemical and disintegrant properties of glutinous rice starch of Mizoram, India”, International Journal of Biological Macromolecules, v. 95, pp. 1298-1304, Feb. 2017.

[19] CHÁVEZ-SALAZAR, A., BELLO-PÉREZ, L.A., AGAMA-ACEVEDO, E., et al., "Isolation and partial characterization of starch from banana cultivars grown in Colombia", International Journal of Biological Macromolecules, v. 98, pp. 240-246, May 2017.

[20] PRABHU, M., CHEMODANOV, A., GOTTLIEB, R., et al., "Starch from the sea: the green macroalga Ulva sp. as a potential source for sustainable starch production from the sea in marine biorefineries", Algal Research, v. 37, pp. 215-227, Jan. 2019.

[21] GANI, A., ASHWAR, B.A., AKHTER, G., et al., "Physico-chemical, structural, pasting and thermal properties of starches of fourteen Himalayan rice cultivars", International Journal of Biological Macromolecules, v. 95, pp. 1101-1107, Feb. 2017.

[22] BASHIR, K., AGGARWAL, M. "Physicochemical, thermal and functional properties of gamma irradiated chickpea starch”, International Journal of Biological Macromolecules, v. 97, pp. 426-433, Apr. 2017.

[23] YONG, H., WANG, X., SUN, J., et al., "Comparison of the structural characterization and physicochemical properties of starches from seven purple sweet potato varieties cultivated in China", International Journal of Biological Macromolecules, v. 120, part B, pp. 1632-1638, Dec. 2018.

[24] CHEN, L., MA, R., ZHANG, Z., et al., "Comprehensive investigation and comparison of surface microstructure of fractionated potato starches”, Food Hydrocolloids, v. 89, pp. 11-19, Apr. 2019.

[25] LI, L., YUAN, T.Z., SETIA, R., et al., "Characteristics of pea, lentil and faba bean starches isolated from air-classified flours in comparison with commercial starches", Food Chemistry, v. 276, pp. 599-607, March 2019.

[26] YIN, Y-AN., QI, J-C., LI, W-H., et al., "Formation and Developmental Characteristics of A- and B-Type Starch Granules in Wheat Endosperm", Journal of Integrative Agriculture, v. 11, n. 1, pp. 73-81, Jan. 2012.

[27] DHITAL, S., SHRESTHA, A.K., GIDLEY, M.J., "Relationship between granule size and in vitro digestibility of maize and potato starches", Carbohydrate Polymers, v. 82, n. 2, pp. 480-488, Sept. 2010.

[28] LI, H., LIU, Y., "Effects of variety and growth location on the chain-length distribution of rice starches", Journal of Cereal Science, v. 85, pp. 77-83, Jan. 2019.

[29] CASTANHA, N., VILLAR, J., MATTA JUNIOR, M.D., et al., "Structure and properties of starches from Arracacha (Arracacia xanthorrhiza) roots”, International Journal of Biological Macromolecules, v. 117, pp. 1029-1038, Oct. 2018.

[30] BASIAK, E., LENART, A., DEBEAUFORT, F., "Effect of starch type on the physico-chemical properties of edible films”, International Journal of Biological Macromolecules, v. 98, pp. 348-356, May 2017.

[31] ZABOT, G.L., SILVA, E.K., EMERICK, L.B., et al., "Physicochemical, morphological, thermal and pasting properties of a novel native starch obtained from annatto seeds", Food Hydrocolloids, v. 89, pp. 321-329, Apr. 2019.

\section{ORCID}

Alana Gabrieli de Souza

Daniel José Silva Viana

Alexandre Soares dos Santos

Valter Carvalho de Andrade Júnior

Derval dos Santos Rosa https://orcid.org/0000-0002-9656-6716

https://orcid.org/0000-0003-1867-6845

https://orcid.org/0000-0003-2417-8084

https://orcid.org/0000-0002-5010-7725

https://orcid.org/0000-0001-9470-0638 